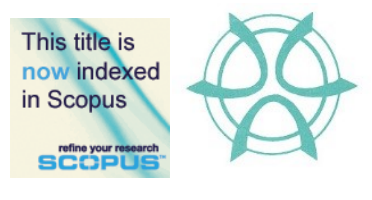

PLANNING MALAYSIA:

Journal of the Malaysian Institute of Planners

VOLUME 18 ISSUE 2 (2020), Page 59 - 72

\title{
IDENTIFYING THE PARAMETERS OF THE MALAY CLASSICAL ARCHITECTURE
}

\author{
Tengku Anis Qarihah bt Raja Abdul Kadir ${ }^{1}$, Puteri Shireen Jahn Kassim², \\ Nurul Syala Abdul Latif ${ }^{3}$, Harlina Md. Shariff ${ }^{4}$ \\ ${ }^{1,2,4}$ Kulliyyah of Architecture and Environmental Design \\ UNIVERSITI ISLAM ANTARABANGSA MALAYSIA \\ ${ }^{3}$ Faculty of Architecture \\ UNIVERSITI SAINS ISLAM MALAYSIA
}

\begin{abstract}
As modernization and urbanization grow, there has been a rising interest in townships with historical elements in their urban landscape. The identification and classification of Malay architectural language are crucial to architects seeking to instill history and culture into the new design. The paper traced the characterizations of classicality in Malay architecture through a thorough study of palaces and aristocrat buildings in Malaysia. Morphological analysis of 50 case studies was mapped but only six palaces from different sites and eras were marked as samples in this paper. The focus of the study not only on their origins, typology, history, and stylistic characters but also on the proportions and elemental attributes of the frontal façade. These case studies were selected as sentinels or samples of successive evolutionary phases in classical Malay architecture which had a huge gap and carried different historical evolutions. It was argued that while the earlier palaces reflected all Malay style attributes, the later expression reflected the cultural pressure of globalization via colonialism diffused from colonial institutions. The study extracted the five parameters of the Malay classical architecture, whereby it was found that even under such pressure, certain features were still maintained to root the identity of the Malays and later developed as new city urbanscape.
\end{abstract}

Keywords: Classical Malay, Malay Identity, Malay architectural language

\footnotetext{
1 Postgraduate Student at International Islamic University Malaysia. Email: nuhadirah@gmail.com
} 
Tengku Anis Qarihah Rj. Abd Kadir, Puteri Shireen Jahn Kassim, Nurul Syala Abd Latiff, Harlina Md. Shariff Identifying the Parameters of The Malay Classical Architecture

\section{INTRODUCTION}

As modernization and urbanization grow at a rapid rate in developing tropical Asian cities, there has been a rising interest in townships that use historical elements of language in their urbanscape. Recent townships by renowned Malaysia developers have utilized imported Classical language to add historical interest to the new township and adorn their commercial and institutional facades. The rise of using 'Classical' stylization is due to the homogeneity of modern 'bare' styling. Mohamad Tajuddin Mohamad Rasdi (2001) stresses that there is local language that can add historical interest to commercial urban landscape, urban forms, and frontages, rather than cut-and-paste solutions. Zhang et al. (2018) said the issues of scale, proportion, what constitutes the essences of local aesthetic characters and parameters that can be used to interpret traditions to the modern building are challenging issues. Global expression and stylistic in public large modern multilevel structures in the Asian city are increasingly modeled upon the Western model or the Arabised-Islamic template. Concerning Malaysia, for example, the interest in the vernacular is due to the dominance of Modernist style public buildings which had spurred a counter-movement.

The identification of Malay templates and resources is also crucial for architects and urban designers seeking to instill history and culture into new building design and development. Within this area, architects are also searching for resources and broad principles and models that can guide them. Within this area, the evolution of construction techniques and works have a dual criticality in Asian tropics, as the materials range from the fragile timber into the modern masonry techniques. Hence classification would not only allow one to recognize the overall stylistic tenor of the work but to gain quick access to technologies and techniques of conservation specific to the material at hand. The aspect and demand for authenticity have additionally highlighted the importance of architectural heritage classification. Llamas et al. (2017) for example, concludes that typological assessment and assessment of heritage into specific classifications is crucial to the preparation of vulnerability analysis and diagnostics, and differentiate building stock according to specific eras and periods, as different classification may require a different approach to the definitions of guidelines and strategies. To provide a cutting line between the Malay architectural language 'from the roots of Malay architecture; from the external Colonial 'tree' of style; one must outline the parameters of the Malay architectural style and its defining character from the roots and branches evolved under the specific cultural and climatic tropical conditions of the Malay architectural tree which is a distinctive vernacular architecture with identifiable features such as layered ventilated roofs, large windows, wide verandas, and ventilated gables. (Ju, Kim, \& Ariffin, 2015) 
PLANNING MALAYSIA

Journal of the Malaysia Institute of Planners (2020)

\section{LITERATURE REVIEW}

Development of policies and strategies and guidelines towards refurbishment, restoration, and enhancement of architectural heritage inherently requires not only a morphological analysis on the evolution of site features of the place but a process of architectural identification and classification. Lee (2015), Llamas et al. (2017) and other summates of the identification of specific styles and classification as part of the conservation process. In architectural design, similar classifications are needed to identify certain approaches to design, without going into the separated elements. Hence according to Lee (2015) and Zhang et al. (2014), one must uncover specific intrinsic yet shared characteristics of architectural heritage to classify them. The southeast Asian tropical region is indisputably rich in diversity of traditions, heritage structures and traditions. Amongst the most characterizing structures are palaces and aristocratic mansions, yet there is a lack of effort to classify and identify common categories of the architectural language of our Malay identity. The difficulty lies in its diversity and transcending such diversities. Thus, the aim must be to identify common identities. Architecturally, Sabrizaa (2014), Mohamad Tajuddin Mohamad Rasdi (2001) and others have debated and discussed in depth the diversity of vernacular houses focusing on traditional houses and also mosques of this region and particularly within the Malay world, there is a rising interest due to the need to establish frameworks of place-making and cultural identity.

An architectural style is characterized by the features that make a building historically identifiable. (Baker et al., 2002) said a style may include elements such as form, method of construction, building materials, and regional character. The evolution of architectural form can be classified as a chronology of styles that had changed over time. (Ju et al., 2015) These changes, at times, are gradual and at times, are abrupt - reflecting changing fashions, beliefs, and religions, or the emergence of new ideas, technology, or materials globally. As a typology, 'palaces' hold a significant position in the Malay community and civilization. They not only represent the center of past socio-political life but are locations of the public life of the past in spatial and temporal terms. Physically and architecturally, they represent the peak of aesthetic sensibilities and capabilities of Malay populations, and collectively represent the identities of these regions of its 'Classicality'. On the definition of Classicality, Frampton (1992) has elaborated: The 'classical' is always conceived as a 'continuous tradition from 'antiquity', and by the mid-18th century, the Classical was a historicist style. 'Classicality' can thus be argued as a temporal attribute related to a kind of refined level and the epitome of civilizational taste, including its styles and symbols, simple in form and comprising a simple hierarchy of formal elements. 
Tengku Anis Qarihah Rj. Abd Kadir, Puteri Shireen Jahn Kassim, Nurul Syala Abd Latiff, Harlina Md. Shariff Identifying the Parameters of The Malay Classical Architecture

\section{METHODOLOGIES}

The methodology adapted to this research is through mapping based on frontages, comparative analysis, and literature reviews. Over 50 case studies of palaces and aristocratic buildings built from the 1700s to 1930s throughout the Malay region were mapped and identified as local evolutions, common parameters and classifying milestones were observed. All of the regions are sharing similar styles and attributes, either the same historical sultanate/ patrons, intermarriage between regions, craftsmen and skill workers, cultural influences and others. The mapping of the Malay palaces and aristocrats helped to categorize the buildings into a group for characterizations. In analyzing this essence, the methods of (Clark \& Pause, 2012) are adapted. The research is not exhaustive; instead, examples are designed to illustrate the nuances of the idea and theory. The analysis of the building frontal façades and forms derived from the consequence of multiple interpretations, dominant patterns and formative features of the buildings by extracting the similar styles/ character of each case study. Sir Banister Fletcher which was known as his Book of History of Architecture had ruled up the importance of categorizing the architectural elements and history through its origins, timeline, and styles.

The subsidiary attributes of culture, politics and others will not be discussed further in this paper as the focus is more on developing the parameters of architectural languages. These will include the building's style, type, proportion, scale, and design principles. The aesthetic styles and functions which focus on the frontage form and façade are defined as the front portion with public spaces. Another main reference for developing the parameters is Palladio from his Ten Book of Architecture. The theory of architecture developed by numerous scholars had clearly shown how to characterize architecture according to groups and clusters. The studies help to convey essential characteristics and relationships of a building frontage which classified a style with specific physical attributes between type, proportion, scale, and composition (Llamas et al., 2017). A parameter or milestones had been developed from the mapping and to be discussed as a comparative analysis between six selected case studies. The attributes to measures the characteristics of the Malay architectural language in this context derived from literature reviews, interviews with craftsmen, designers and historians. The case studies were selected accordingly to represent different major periods, i.e. the early 1700 s, late 1700 s, late 1800 s, early 1900 s and eventually the 1930s, consist of Istana Rokan Sumatera, Istana Balai Besar Kedah, Istana Hulu Perak, Baitul Rahmah Perak, Istana Sepahchandera Kedah and Istana Woodneuk, Singapore represent the temporal and geographical differentiation were compare in table 1 . 
Table 1: The Comparison of Case Studies

\begin{tabular}{|c|c|}
\hline \multicolumn{2}{|l|}{ Case Studies } \\
\hline $\begin{array}{l}\text { Istana Rokan, Sumatera, Indonesia. } \\
\text { Built-in the Year } 1770 \\
\text { Rokan Palace is a relic of the } 200 \text {-year-old } \\
\text { "Nagari Tuo" sultanate has a unique collection of } \\
\text { Royal Rokan IV Koto carving, with dragon- } \\
\text { carved engravings, plants ornamentations, and } \\
\text { unique form of building. }\end{array}$ & okan \\
\hline $\begin{array}{l}\text { Istana Balai Besar, Kedah, Malaysia. } \\
\text { Built-in the Year } 1730 \\
\text { The form survived through the tumultuous era of } \\
\text { the late } 1800 \text { s and early } 1900 \mathrm{~s} \text { of external } \\
\text { attacks, fire, and colonization but still retained } \\
\text { the essence of Malay architecture even though } \\
\text { with infusion of masonry and technology of cast } \\
\text { iron. }\end{array}$ & Sid \\
\hline $\begin{array}{l}\text { Istana Hulu, Perak, Malaysia. } \\
\text { Built in the Year } 1903 \text {. } \\
\text { It was believed that Captain Maurice Alexander } \\
\text { Cameron, the Deputy Colonial Engineer ( } 1883 \\
\text { and 1892), was the one who designed the art } \\
\text { forms and construction of this castle but with } \\
\text { orders by Sultan, the essence of Malay } \\
\text { architecture still can be found. }\end{array}$ & \\
\hline $\begin{array}{l}\text { Baitul Rahmah, Perak, Malaysia. } \\
\text { Built-in the Year } 1911 \\
\text { It is an example of a Malay-Perak variation of a } \\
\text { Classical vernacular language. At the corner part } \\
\text { of the roof fascia of the villa are elements } \\
\text { decorated with carving inspired by the character } \\
\text { of honey bees. It was designed to complement the } \\
\text { 'buton' woodcarving elements. }\end{array}$ & Side Elevation of Baitul Rahmah \\
\hline $\begin{array}{l}\text { Istana Che Sepahchandera, Kedah, Malaysia. } \\
\text { Built-in the Year } 1911 \\
\text { The Sepachendera Palace was built for the wife } \\
\text { of Sultan Abdul Hamid Halim Shah (1882-1943) } \\
\text { Che Sepachendera. The palace is built with three } \\
\text { floors and has a flat roof. On the ground floor is } \\
\text { the public area while upper floors are for royals. }\end{array}$ & $\begin{array}{l}\text { Af } \\
\text { Front Elevation of Istana }\end{array}$ \\
\hline
\end{tabular}


Tengku Anis Qarihah Rj. Abd Kadir, Puteri Shireen Jahn Kassim, Nurul Syala Abd Latiff, Harlina Md. Shariff Identifying the Parameters of The Malay Classical Architecture

Istana Woodneuk, Singapore.

Built-in Year 1930s.

Istana Woodneuk was built for the Sultan's fourth wife Sultana Khadijah in 1890 and took two years to complete. The blue-roof palace consisting of the main building with two smaller houses by its side.

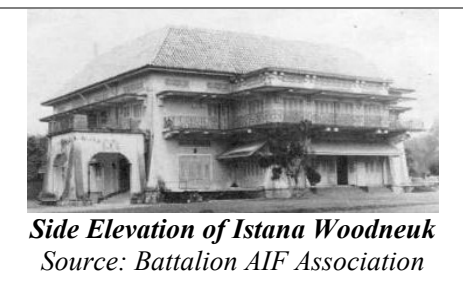

\section{FINDINGS AND DISCUSSION}

The Malay Frontage Character

Throughout the mapping of the 50 case studies was observed, the parameters of the Malay evolving style to differentiate from the colonial tree of style had been developed. The frontages may evolve into masonry versions, yet still be identified as Malay, if it complies with essential rules of character based on parameters of identification. These can be used to assess a language despite the pressure or evolution of change. These variations are rooted in a series of ancient models which is also the highpoint of aesthetic language. From the 50 or more case studies, the Five parameters of defining a classical Malay Architectural language rooted in Malay world summarised as follows:

1) Origins and Typologies

2) The Stylistic Grammar

3) The Building's Shape and Form; Ratio and Proportion

4) Expression of Structure and Construction

5) The Detailing of Decorative and Architecture Elements

\section{a) The Origins and Basic Typologies}

To define whether a frontage is Malay Classical, one must refer back to the theory of origins as the center of its culture. In the Malay world, the center of its culture arises from its history which is rooted back into the Riau Srivijaya region and these sites have been mapped and documented where their expressive language traced (Reid, 2004). Its rootedness must be traced towards the point of its dissemination into the neighboring region, diaspora and other parts of the region (Shireen, Kassim, Hanita, \& Majid, 2017). Many historians (Andaya, 2008; Milner 2011) support the views that the Southeast polities of Sumatera are primarily the Malay ancestral homeland. Thus, a Malay Classical architecture; can be traced back to the roots of its style. Its patron or proponent must have originated and located within the Malay Kingdom or 'Nusantara Land'. The buildings should be owned or built by Malay aristocrat or patron or owners and dominated by decisions by a Malay patron who is instrumental in asserting Malay architectural identity. 
PLANNING MALAYSIA

Journal of the Malaysia Institute of Planners (2020)

Table 2: The Origins and Typologies Characteristics: The Six Case Studies

\begin{tabular}{|c|c|c|c|c|c|c|}
\hline $\begin{array}{c}\text { Case } \\
\text { Studies }\end{array}$ & $\begin{array}{c}\text { Istan } \\
\text { a } \\
\text { Roka } \\
\text { n } \\
\end{array}$ & $\begin{array}{l}\text { Is. Balai } \\
\text { Besar }\end{array}$ & $\begin{array}{c}\text { Istana } \\
\text { Hulu }\end{array}$ & $\begin{array}{c}\text { Baitul } \\
\text { Rahmah }\end{array}$ & $\begin{array}{c}\text { Istana } \\
\text { Sepachendra }\end{array}$ & $\begin{array}{c}\text { Istana } \\
\text { Woodneuk }\end{array}$ \\
\hline Location & Riau & Kedah & Perak & Perak & Kedah & Singapore \\
\hline Years Built & 1750 & 1735 & 1903 & 1911 & 1882 & 1890 \\
\hline Built For & $\begin{array}{c}\text { Sulta } \\
\mathrm{n}\end{array}$ & Sultan & Sultan & Sultanah & Sultanah & Sultanah \\
\hline Built By & $\begin{array}{c}\text { Local } \\
\text { peopl } \\
\text { e }\end{array}$ & $\begin{array}{l}\text { Local } \\
\text { People }\end{array}$ & $\begin{array}{l}\text { Local } \\
\text { people }\end{array}$ & $\begin{array}{l}\text { Local } \\
\text { People }\end{array}$ & $\begin{array}{l}\text { Siamese \& } \\
\text { Local }\end{array}$ & $\begin{array}{l}\text { Local \& } \\
\text { Chinese }\end{array}$ \\
\hline $\begin{array}{l}\text { Designed } \\
\text { By }\end{array}$ & $\begin{array}{c}\text { Sulta } \\
n\end{array}$ & $\begin{array}{c}\text { Sultan \& } \\
\text { Artisan }\end{array}$ & $\begin{array}{c}\text { Sultan \& } \\
\text { British }\end{array}$ & $\begin{array}{c}\text { Sultan \& } \\
\text { Artisan }\end{array}$ & $\begin{array}{c}\text { Sultan \& } \\
\text { Artisan }\end{array}$ & British \\
\hline
\end{tabular}

Though located within the 'Malayness territory' (Reid, 2004) certain designs and forms were initiated by foreign architects or advocates although the patron is a Malay. As refer to table 2, for Istana Sepachendra and Istana Woodneuk, although these seem eclectic or British, the advocates or patrons are Malay and design administered by a Malay. For Istana Hulu, the frontage is designed by a British officer, but the Sultan had asserted a degree of the identity of Melayu in the design. A sample of this identification is in Table 4 below. The attributes below marked how the palaces were being designed as such and how it is carried out. All of these attributes and influences lead to the authenticity of the architecture.

\section{b) The Stylistic Grammar}

An architectural style is characterized by the grammar of language whose elements make it notable or historically identifiable. A grammar is a set of elements or technique which may include such elements as form, a method of construction and regional character. Any local decorative style can be influenced by the design style such as Neo-Gothic, Baroque and Neoclassical, Dutch Patrician, Art Deco and International Style (SeoRyungJu \& Omar, 2011). Malay architecture cannot avoid certain evolutions and hybridization. Although a Malay style can be infused by Colonial or 'global' elements, if a case contains more than $50 \%$ of the Malay detailed elements, then it is classical. From a range between the poles of 'Malay to Globalization' and 'Globalization to Malay', the degree of Malayness is the more than half -fulfillment of these elements to define the dominant style of Malayness in the overall language of the building. Table 3 shows the stylistic characters of the case studies. For Istana Hulu's conflicting character i.e. the roof form, fascia, and finial but lack the Malay columns, thus the front part of its elevation is essentially colonial while the side elevations are Malay Classical. Istana Sepachendra has foreign influences with elements of the Corinthian grammar; thus, it is not Malay Classical but essentially an eclectic language with a Malay form due to its central portico and the 
Tengku Anis Qarihah Rj. Abd Kadir, Puteri Shireen Jahn Kassim, Nurul Syala Abd Latiff, Harlina Md. Shariff Identifying the Parameters of The Malay Classical Architecture

triangular shape of gable end with slender columns. The building's architecture can be deemed as essentially an eclectic language due to the influence of the reigning Jawi Peranakan style in British Penang at the time with a Moorishshaped déco and features of local ornaments found at the railings.

Table 3: Shows the Stylistic Grammar of The Case Studies

\begin{tabular}{|c|c|c|c|c|c|c|}
\hline $\begin{array}{l}\text { Case } \\
\text { Studies }\end{array}$ & $\begin{array}{l}\text { Istana } \\
\text { Rokan }\end{array}$ & $\begin{array}{c}\text { Istana } \\
\text { Balai Besar }\end{array}$ & $\begin{array}{l}\text { Istana } \\
\text { Hulu }\end{array}$ & $\begin{array}{c}\text { Baitul } \\
\text { Rahma } \\
\text { h } \\
\end{array}$ & $\begin{array}{c}\text { Istana } \\
\text { Sepachendr } \\
\mathbf{a} \\
\end{array}$ & $\begin{array}{c}\text { Istana } \\
\text { Woodneu } \\
\mathbf{k} \\
\end{array}$ \\
\hline Stylistic & $\begin{array}{c}\text { Malay } \\
\text { Classic } \\
\text { al }\end{array}$ & $\begin{array}{c}\text { Malay } \\
\text { NeoClassical }\end{array}$ & $\begin{array}{c}\text { Malay } \\
\text { Colonial }\end{array}$ & $\begin{array}{c}\text { Syncretic } \\
\text { Malay }\end{array}$ & Anglo Malay & Modern \\
\hline $\begin{array}{l}\text { Malay To } \\
\text { Global }\end{array}$ & $\sqrt{ }$ & $\sqrt{ }$ & $\sqrt{ }$ & $\sqrt{ }$ & - & - \\
\hline $\begin{array}{l}\text { Global To } \\
\text { Malay } \\
\end{array}$ & - & - & $\sqrt{ }$ & - & $\sqrt{ }$ & $\sqrt{ }$ \\
\hline
\end{tabular}

\section{c) The Shape, Form, Ratio, and Proportion}

Figure 1 below represents the Generic and Variant Forms of Malay architecture, essentially derived from the five 'generic' Classical formal typologies of Malay aristocratic frontages and facades (Anis et al., 2018). The work of Clark, \& Pause (2012) was used to identify essential types of the Malay façade based on aristocratic compositions and elevations. All frontage can be classified and organized according to the five types, despite variations due to neighboring influences and variations according to evolution or dominant material (Refer to Figure 1 and Table 1). Example of Istana Baitul Rahmah Perak has a binuclear form with the 'double' extended portico or verandah organized with roof finials and decorative panels, similar to Istana Hulu with two vertical towers on the left and right side of the building.

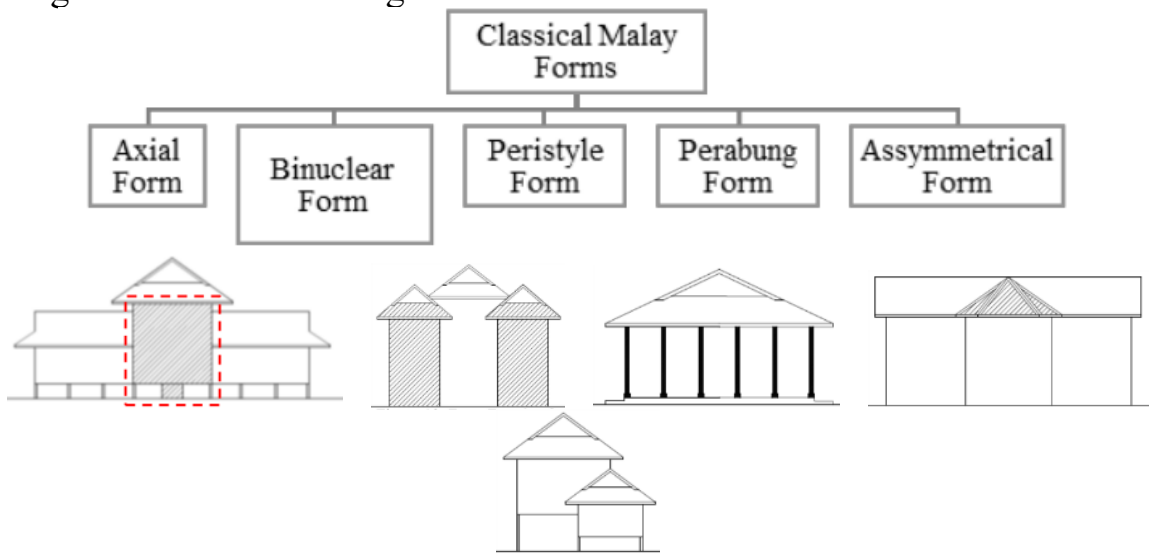

Figure 1: Observed Typologies of Classical Malay Forms Sources: Anis et al., 2016 
While the Colonial Classical is defined by Greek-based proportions such as 1: 7 in defining column proportions, the Malay column proportion exceeds this ratio. Anis et al. (2018) and Sabrizaa (2014) has discussed the ratio of solids and voids. Similarly, the Malay classical style would have its specific ratio of the proportion of ground floor to the upper floor, roof and wall and openings and wall. Table 4 below highlights a certain ratio found. The form description refers to Figure 1.

Table 4: Form, Ratio, and Proportion of six Frontages

\begin{tabular}{c|cccccc}
\hline $\begin{array}{c}\text { Case } \\
\text { Studies }\end{array}$ & $\begin{array}{c}\text { Istana } \\
\text { Roka } \\
\mathbf{n}\end{array}$ & $\begin{array}{c}\text { Is. } \\
\text { Balai } \\
\text { Besar }\end{array}$ & $\begin{array}{c}\text { Istana } \\
\text { Hulu }\end{array}$ & $\begin{array}{c}\text { Baitul } \\
\text { Rahmah }\end{array}$ & $\begin{array}{c}\text { Istana } \\
\text { Sepachendra }\end{array}$ & $\begin{array}{c}\text { Istana } \\
\text { Woodneuk }\end{array}$ \\
\hline Form & Axial & Peristyle & Binuclear & Binuclear & Axial & - \\
\hline $\begin{array}{c}\text { Proportion } \\
\text { Roof: Wall }\end{array}$ & $1: 1$ & $1: 1$ & $1: 1$ & $1: 2$ & $0.5: 1$ & $1: 2$ \\
\hline $\begin{array}{c}\text { Column: } \\
\text { Diameter }\end{array}$ & $1: 16$ & $1: 25$ & $1: 7$ & $1: 7$ & $1: 11$ & $1: 7$ \\
\hline $\begin{array}{c}\text { Openings: } \\
\text { Wall }\end{array}$ & $1: 1$ & $1: 1$ & $1: 2$ & $1: 1$ & $1: 2$ & $1: 3$ \\
\hline $\begin{array}{c}\text { External } \\
\text { Ornaments }\end{array}$ & $\sqrt{ }$ & $\sqrt{ }$ & $\sqrt{ }$ & $\sqrt{ }$ & $\sqrt{ }$ & $\mathrm{x}$ \\
\hline
\end{tabular}

-The Malay Sense of Aesthetic Proportion

Despite differences in formal typology, the sense of proportion still exists as frontages fit into the Golden ratio. Table 5 below highlights how the Malay frontages reflect an innate sense of proportion by the Malays who are consistently building based on the human proportion. When assessed using the Golden ratio, it is found that many facades obey the essential parameters of the Golden ratio i.e. 1.618. As the case studies were tested on a series of these Malay frontages, the anthropocentric and balance composition were found. It can be deduced that due to the Malay anthropocentric way and method of measurement. Certain findings by the Western cannot necessarily be generalized across cultures but can be the reference for the Malays to have one. 
Tengku Anis Qarihah Rj. Abd Kadir, Puteri Shireen Jahn Kassim, Nurul Syala Abd Latiff, Harlina Md. Shariff Identifying the Parameters of The Malay Classical Architecture

Table 5: The Malay Frontage Reflects Sense of Proportion - Golden Ratio Survived through the Evolution of Malay Frontage

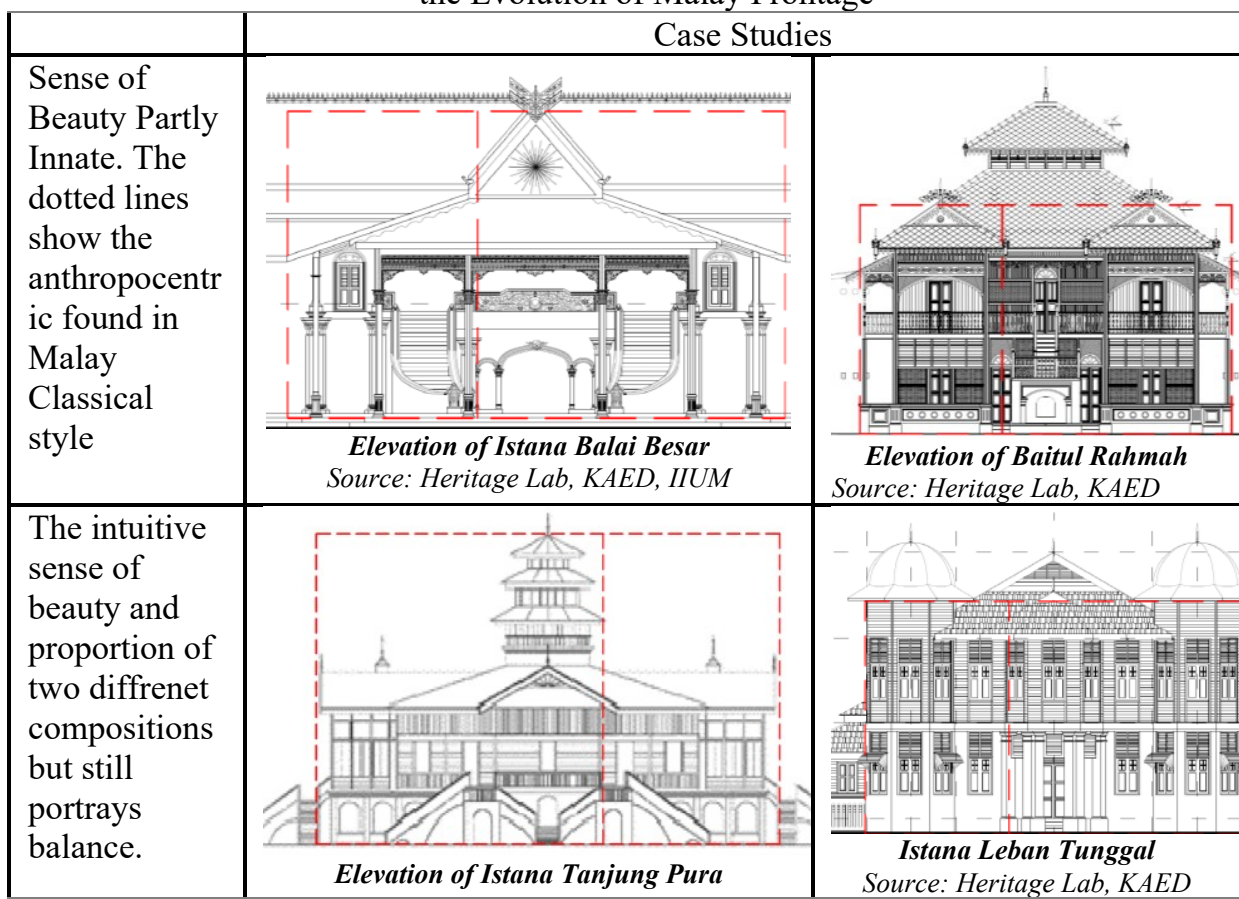

\section{d) Expression of Structural System and Construction}

The origins of the Malay architectural language is typically discussed as a timberbased vernacular style (Said, 2005), which had to absorb other influences evolving into a hybrid language of timber, masonry and cast iron (Jahn Kassim, Puteri Shireen, Abdul Majid, Noor Hanita, Nawawi, 2017). The Malay vernacular tradition then had undergone a transposition of such forms and principles onto fundamental functions, typologies, construction, and methods (Zumahiran Kamarudin \& Ismail Said, 2008). There is a synchronization between the Colonial language and the Malay language, infused with elements of neighboring influences. Figure 2 below summarises the five evolving hybrid types of materials and constructions of Malay frontages in palaces. The Malay essential style expresses its structural system rather than cloaking it. As discussed by Zhang et al. (2018), a vernacular style will evolve from timber into a total masonry expression. The Malay Classical style would assert its tectonic expression as it evolves into masonry. The Malay character evolving hybrid style, with different extents of timber and masonry. Although it has the essential hybridity identified in Table 6, the Malay Classical style would assert its tectonic language that expresses its structure and constructional system (Frampton, 1981). 


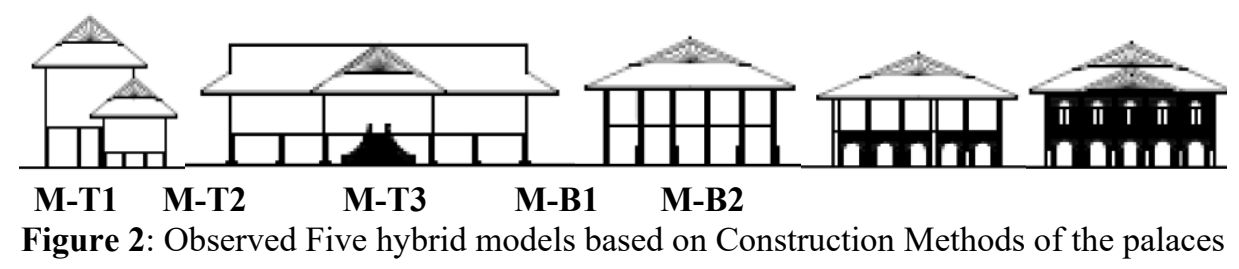

Table 6: shows the coding for the materials according to the case studies

\begin{tabular}{|c|c|c|c|c|c|c|}
\hline CODING & \multicolumn{5}{c|}{ Materials } \\
\hline M-T1 & \multicolumn{5}{c|}{ All Timber } \\
\hline M-T2 & \multicolumn{5}{|c|}{ All Timber Except Staircase and Ground Column } \\
\hline M-T3 & \multicolumn{5}{c|}{ Ground Column and Wall Are Bricks, Others Timber } \\
\hline \multicolumn{2}{|c|}{ M-B1 } & \multicolumn{5}{|c|}{ Anly Ground Fl. Brick, Others Timber } \\
\hline \multicolumn{2}{|c|}{ M-B2 } & \multicolumn{1}{|c|}{ Istant Except Roof Components } \\
\hline Case & Istana & Balai & Istana & Baitul & Istana & Istana \\
Studies & Rokan & Besar & Hulu & Rahmah & Sepachendra & Woodneuk \\
\hline Materials & M-T1 & M-T2 & M-B2 & M-T1 & M-B2 & MB2 \\
\hline
\end{tabular}

\section{e) The Detailing of Decorative and Architecture Elements}

There is a controlled ornamentation in the definition of the Malay character in its visual form. The Malay ornamentation is essentially art formed from a specific pattern and environment with a specific composition of motif which links the Malay style back to an essentially ecological style of nature's vegetal and flora patterns (Ismail Jasmani et. al., 2019) whose elements adorn the edged of functional elements of frontages and roofs. These are an essential part of the spirit of the Malays who had observed and coordinated their designs by specified principles and ornamental expertise usually produced for a particular local identity and to sustain the aesthetic elements in establishing a local identity. Table 7 below highlights the presence of these elements in each case study mentioned. List of stylistic characters and attributes were collected from literature reviews, interviews with wood craftsmen and historians. 
Tengku Anis Qarihah Rj. Abd Kadir, Puteri Shireen Jahn Kassim, Nurul Syala Abd Latiff, Harlina Md. Shariff Identifying the Parameters of The Malay Classical Architecture

Table 7: Some of The Crafted Detailing of Malay Decorative Architecture Elements

\begin{tabular}{|c|c|c|c|c|c|}
\hline $\begin{array}{l}\text { Stylistic } \\
\text { Character }\end{array}$ & $\begin{array}{c}\text { Istana } \\
\text { Rolkan Riau } \\
\end{array}$ & $\begin{array}{c}\text { Istann Balni } \\
\text { Besar, Kedah }\end{array}$ & $\begin{array}{c}\text { Istana Hulu, } \\
\text { Perak }\end{array}$ & $\begin{array}{c}\text { Baitul } \\
\text { Rahmah, }\end{array}$ & $\begin{array}{c}\text { Istana Scpa } \\
\text { chendra }\end{array}$ \\
\hline RonfTinial & & & & & $X$ \\
\hline $\begin{array}{l}\text { Barge } \\
\text { Board }\end{array}$ & & & $\mathrm{X}$ & & \\
\hline $\begin{array}{l}\text { Gable } \\
\text { End }\end{array}$ & & & $\mathrm{X}$ & & \\
\hline
\end{tabular}

Istana Woodneuk does not have any of these attributes. This stylistic character's table/chart helps to measure the authenticity of a Malay building with stylistic elements that are supposed to be found in Malay buildings.

\section{CONCLUSION}

Despite the huge gap in time and changes in architectural evolution and style, there are common parameters that survive. The characters and the main elements of the Malay Classical style are also highlighted due to their consistent appearance in the public aristocratic architectural language. The study helped to identify and classify, which were genuinely Malay architecture and have gone through assimilation and changes. It was until at certain parameters or milestones, that a building could no longer be accepted as classical Malay architecture. From the findings, now people can measure the levels of authenticity of Malay architectural language, the attributes and principles a Malay architecture building should have. The principles of the character from the root to the last branch of the Malay essence can be discovered by following the five parameters. Classical Malay architecture can be very well transmuted with modern technology as long as we know which character should be highlighted in the design. Amidst the disappearing of identity in the modern world, this can be developed and become the public language for the new cities and urbanscapes, which must go beyond any cosmetic or cut-and-paste architecture and reflect the region. These architectural styles will be the benchmarks in society, leaving a lasting legacy that continues the future. 
PLANNING MALAYSIA

Journal of the Malaysia Institute of Planners (2020)

\section{ACKNOWLEDGMENTS}

The authors would like to acknowledge the Transdisciplinary Research Fund TRGS/1/2016/UIAM/01/5/2 from the Ministry of Higher Education for the support of this research.

\section{REFERENCES}

Anis, T., Raja, Q., Kadir, A., Shireen, P., Kassim, J., Hanita, N., ... Nawawi, M., (2018). Classical Hybrid Language of Malay Aristocratic Buildings Identifying Generic and Variant Forms, Journal of the Malaysian Institute of Planners 16 (2), pp304 - 322

Baker, P., Barson, S., Cole, E., Flemingto, M., Gee, E., Gibson, T., ... Yinong, X., (2002). Architectural Details - A Visual Guide to 5000 Years of Building Styles. (S. Luck, Ed.) (First Edit). United Kingdom: Ivy Press.

Clark, R. H. \& Pause, M., (2012). Precedents in Architecture; Analytic Diagrams, Formative Ideas and Parts (Fourth). New Jersey: John Wiley \& Sons, Inc.

Frampton, K., (1992). Modern Architecture: A Critical History (Third Edition, Revised and Enlarged). London: Thames and Hudson.

Ismail Jasmani, Norzalifah Zainal Abidin, Shamzani Affendy Mohd Din, Puteri Shireen Jahn Kassim, (2019). Architecture Ecologised: Nature's Patterns and Abstractions in Malay Built Traditions. Cultural Syndrome Journal, Vol. 1 (2), 2019, Univeristy of Unindra.

Jahnkassim, Puteri Shireen, Abdul Majid, Noor Hanita, Nawawi, N., (2017). The Resilience of Tradition; Malay Allusions in Contemporary Architecture (First). Penang: Areca Books.

Ju, S. R., Kim, B. M., \& Ariffin, S. I., (2015). Continuation and Transformation of Traditional Elements in Colonial Vernacular Houses in Kampong Bharu, Malaysia. Journal of Asian Architecture and Building Engineering.

Lee, S., Maisonneuve, N., Crandall, D., Efros, A. A., \& Sivic, J., (2015). Linking Past to Present: Discovering Style in Two Centuries of Architecture. 2015 IEEE International Conference on Computational Photography (ICCP).

Llamas, J., M. Lerones, P., Medina, R., Zalama, E., \& Gómez-GarcíaBermejo, J., (2017). Classification of Architectural Heritage Images, Applied Sciences, 7(10), 992.

Milner, A., (2004). Afterword: A History of Malay Ethnicity. In T. P. Barnard (Ed.), Contesting Malayness- Malay Identity Across Boundaries, Singapore Uni Press.242257

Mohamad Tajuddin Mohamad Rasdi, (2001). Seni Bina dan Permasalahan Identiti. In Identiti Seni Bina Malaysia Kritikan Terhadap Pendekatan Reka Bentuk (pp. 1-8).

Reid, A., (2004). Understanding Melayu (Malay) as a Sources of Diverse Modern Identity. In T. P. Barnard (Ed.), Contesting Malayness- Malay Identity Across Boundaries (First Edit, pp. 1-24). Singapore: Singapore University Press.

Sabrizaa, M. R., A., \& Amat, S. C., (2014). Local Genius Revisited (March), 28-31.

Said, I., (2005). Criteria for Selecting Timber Species in Malay Woodcarving. Journal of Asian Architecture and Building Engineering, 4(1), 17-23. https://doi.org/10.3130/jaabe.4.17

SeoRyungJu, \& Omar, S. B., (2011). A typology of Modern Housing in Malaysia. 1st South East Asia Housing Forum of ARCH, Seoul, Korea, 11(June), 1-12.

Shireen, P., Kassim, J., Hanita, N., \& Majid, A., (2017). A definition of Malay Classicality amidst Colonial change: Deriving language, principles and forms 
Tengku Anis Qarihah Rj. Abd Kadir, Puteri Shireen Jahn Kassim, Nurul Syala Abd Latiff, Harlina Md. Shariff Identifying the Parameters of The Malay Classical Architecture

Shomali, F. M., (2000). The gnomonic theory of architecture: a computational theory of the geneology of design. PQDT - UK \& Ireland.

Andaya, Y. L., (2004). The Search for the 'Origins' of Melayu. In T. P. Barnard (Ed.), Contesting Malayness- Malay Identity Across Boundaries, Singapore Uni Press.56-75

Zhang, L., Song, M., Liu, X., Sun, L., Chen, C., \& Bu, J., (2014). Recognizing architecture styles by hierarchical sparse coding of blocklets, Information Sciences, 254(1), 141 154.

Zumahiran Kamarudin \& Ismail Said, (2008). Visual Forms of Carved Components in Traditional Timber Houses of Kelantan and Terengganu. Jurnal Alam Bina.

Received: January 2020. Accepted: $1^{\text {st }}$ April 2020 